\title{
Mechanistic Evidence for Red Meat and Processed Meat Intake and Cancer Risk: A Follow-up on the International Agency for Research on Cancer Evaluation of 2015
}

\author{
Robert J. Turesky*
}

\begin{abstract}
The Working Group of the International Agency for Research on Cancer classified the consumption of processed meat as carcinogenic to humans (Group 1), and classified red meat as probably carcinogenic to humans (Group 2A); consumption of both meat types is associated with an increased risk of colorectal cancer. These classifications are based on a compilation of epidemiology data and mechanistic evidence from animal and human studies. The curing of meats with nitrite can produce carcinogenic $N$-nitroso compounds (NOCs), and the smoking of meat produces polycyclic aromatic hydrocarbons (PAHs). The high-temperature cooking of meat also produces carcinogenic heterocyclic aromatic amines (HAAs). The ingestion of heme from meat can catalyze the formation of NOCs and lipid peroxidation products (LPOs) in the digestive tract. Many of these chemicals form DNA adducts, some of which can induce mutations and initiate carcinogenesis. Another recent hypothesis is that $\mathrm{N}$-glycolylneuraminic acid, a non-human sialic acid sugar present in red meat, becomes incorporated in the cell membrane, triggering the immune response with associated inflammation and reactive oxygen species, which can contribute to DNA damage, tumor promotion, and cancer. The mechanisms by which these chemicals in meat induce DNA damage, and the impact of dietary and host factors that influence the biological potency of these chemicals are highlighted in this updated report.
\end{abstract}

Keywords: Colorectal cancer · DNA damage $\cdot$ Genotoxicant

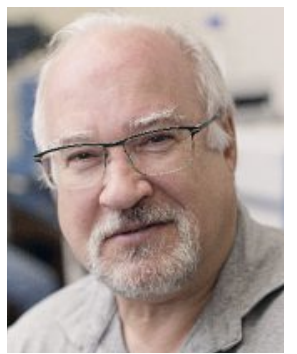

Dr. Robert Turesky is a Professor in the Department of Medicinal Chemistry, and Director of the Masonic Cancer Center's Analytical Biochemistry shared resource, a mass spectrometry facility devoted to the cancer and chemoprevention programs at the University of Minnesota. Dr. Turesky received his $\mathrm{PhD}$ in nutrition and food science from M.I.T. Prior to his current position, Dr. Turesky served as Group Leader of the Biomarkers Unit, Nestlé Research Center, Lausanne, Switzerland (19862000); Division Director of Chemistry, National Center for Toxicological Research,

${ }^{*}$ Correspondence: Prof. R. J. Turesky Masonic Cancer Center

Department of Medicinal Chemistry

College of Pharmacy, University of Minnestoa

2231 6th St SE,

Minneapolis, MN, USA

E-mail: Rturesky@umn.edu
U.S. Food and Drug Administration, Jefferson, AR, (2000-2004); and Principal Investigator, Wadsworth Center, New York State Department of Health (2004-2013). He investigates the biochemical toxicology of dietary and environmental genotoxicants and applies mass spectrometry methods to identify and measure biomarkers of these chemicals in molecular epidemiology studies that seek to understand the role of chemical exposures in the etiology of cancer.

\section{Introduction}

Colorectal cancer $(\mathrm{CRC})$ is the third most commonly diagnosed cancer and the third leading cause of cancer death in both men and women in the United States. ${ }^{[1]}$ The risks for developing CRC are thought to be attributed to lifestyle factors such as the diet, alcohol and tobacco usage, physical exercise, and obesity. ${ }^{[2]}$ The differences in rates of CRC in different geographic locations and temporal changes in risk among immigrant populations suggest that diet and lifestyle strongly influence the occurrence of $\mathrm{CRC}$, and that inherited genetic mutations account for a minor percentage of CRC incidence. ${ }^{[1,3]}$ Single nucleotide polymorphisms in genes that encode for carcinogen metabolism enzymes that influence the biological activity of procarcinogens, ${ }^{[4-6]}$ epigenetic factors, aberrant microRNA activity, and chronic inflammation contribute to the development of CRC. ${ }^{[7,8]}$ Recently, the role of the intestinal bacterial flora has emerged as an increasingly important factor in CRC. ${ }^{[9]}$ However, the definitive biochemical mechanisms and causative factors contributing to DNA damage, mutations, and development of $\mathrm{CRC}$ remain unclear.

In 2015, a Working Group convened at the International Agency for Research on Cancer (IARC) in Lyon, France, to evaluate the carcinogenicity of the consumption of red meat and processed meat. In a report published in Lancet Oncology, ${ }^{[10]}$ the Working Group reported that "On the basis of the large amount of data and the consistent associations of colorectal cancer with consumption of processed meat across studies in different populations, which make chance, bias, and confounding unlikely as explanations, a majority of the Working Group concluded that there is sufficient evidence in human beings for the carcinogenicity of the consumption of processed meat." A large body of epide- 
miological studies have reported that the consumption of processed meats and red meats are risk factors for colorectal cancer (CRC). ${ }^{[11-13]}$ Processed meat was classified as carcinogenic to humans (Group 1 ), and red meat was classified as probably carcinogenic to humans (Group 2A). The consumption of red meat was also reported to be positively associated with pancreatic and prostate cancer and processed meat with gastric cancer. However, the Working Group noted that there was inadequate evidence in experimental animals for the carcinogenicity of consumption of red meat and of processed meat. The mechanistic evidence was based on genotoxic effects of certain processed meats or red meats, or some of their components in experimental rodent models. ${ }^{[12,14-16]}$

The Working Group defined red meat as unprocessed mammalian muscle meats, including beef, veal, pork, lamb, mutton, horse, or goat. Red meat is usually consumed cooked. Processed meat was defined as meat treated through salting, curing, fermentation, smoking, or other processes to enhance flavor or improve preservation. Most processed meats contain pork or beef, but might also contain other red meats, offal (for example liver), or meat byproducts such as blood. ${ }^{[10]}$

Several classes of carcinogens formed in processed and cooked red meats are proposed to contribute to CRC: $N$-nitroso compounds (NOCs) in nitrited-cured meats; ${ }^{[17,18]}$ heterocyclic aromatic amines (HAAs) formed in well-done cooked red meats and poultry; $[19,20]$ and polycyclic aromatic hydrocarbons (PAHs) formed in smoked meats and meats cooked under flame. ${ }^{21]}$ In addition, ingested heme can catalyze the nitrosation of endogenous secondary amines ${ }^{[14]}$ and exert pro-oxidative effects by catalysis of lipid peroxidation in the gastrointestinal tract. ${ }^{[16]}$ All of these chemicals can form DNA adducts, and if not repaired by enzyme systems, [22] some of the DNA adducts can induce mutations during cell division and lead to the development of cancer. ${ }^{23]}$ IARC has classified several NOCs and PAHs as Group 1 carcinogens, and several HAAs are designated as Group 2A or 2B carcinogens. The identification of the causative agents involved in the development of CRC is important since the modification of diets or changes in the methods of preparing meats can mitigate some chemical exposures that contribute to the cancer burden. ${ }^{[24]}$ Some epidemiologic studies have reported an elevated risk for $\mathrm{CRC}$ and other cancers with consumption of meats cooked well-done at high temperatures, whereas other studies have not found this association. ${ }^{[25-31]}$ Thus, the dietary data have been suggestive but inconsistent. A main limiting factor in epidemiological studies is the uncertainty in the quantitative estimates of chronic exposure to different types of carcinogens in meat. The concentrations of genotoxicants in meat can range over 100-fold, depending on the processing and methods of cooking meat. There is a critical need to develop and employ specific and quantitative measurements of stable, long-lived biomarkers for reliable assessments of exposures, estimation of the biologically effective dose, and the DNA damage induced by chemicals in processed and red meats for human risk assessment. ${ }^{[32-34]}$ Some of these prototypical chemical carcinogens in meat and their mechanisms of DNA damage, and the impact of dietary and host factors that influence the biological potency of these chemicals are presented in this updated report.

\subsection{Mechanisms of Genomic Damage and DNA Adduct Formation by Components in Processed and Cooked Meat}

The proposed biochemical mechanisms by which genotoxicants and components in processed and red meat induce DNA damage in the colorectum are depicted in Fig. 1.

N-Nitroso compounds. Carcinogenic NOCs formed during the curing of meats with nitrite include $N$-nitrosodimethylamine (NDMA), $\mathrm{N}$-nitrosodiethylamine, $\mathrm{N}$-nitrosodibutylamine, $\quad N$-nitrosopyrrolidine, and $\mathrm{N}$-nitrospiperidine. The levels of NOCs in cured meats range from less than one part-per-billion (ppb) up to 130 ppb.[17,18] NOCs undergo metabolic activation by cytochrome P450 2E1 expressed in the GI tract. ${ }^{[37]}$ For example, the reactive methyl- ating intermediate of NDMA forms $N 7$ methyl-2'-deoxyguanosine (N7-MedG), which leads to abasic site formation, DNA strand breaks, and cytotoxicity. ${ }^{[38]}$ Another adduct occurs through $O^{6}$-methylation of deoxyguanosine $(\mathrm{dG})$ to form $O^{6}$-methyl2'-deoxyguanosine ( $O^{6}-\mathrm{MedG}$ ) (Fig. 2). ${ }^{[39]}$

Recent attention has focused on endogenously formed NOCs, which become elevated in the gastrointestinal tract following consumption of processed or red meats.[14] Nitrosated glycine, dipeptides, or $N$-nitroso bile acid conjugates, such as $N$-nitrosoglycocholic acid, form $O^{6}$-MedG and $O^{6}$-carboxymethyl-2'-deoxyguanosine $\left(O^{6}-\mathrm{CMdG}\right)$ (Fig. 2), ${ }^{[39]}$ which induce $\mathrm{G}-\mathrm{A}$ transitions and $\mathrm{G}-\mathrm{T}$ transversions that may contribute to the mutations in cancer driver genes, including $\mathrm{H}$-ras and $K$-ras oncogenes and the $p 53$ tumor suppressor gene, in the gastrointestinal tract of omnivores. ${ }^{[40,41]}$ The levels of endogenously produced NOCs in feces of healthy human subjects on a fresh red meat- or processed meat diet were ten-fold or greater than those levels formed in feces of volunteers on a vegetarian diet, and the percentage of colonic exfoliated cells staining positive for $O^{6}-\mathrm{CMdG}$ was significantly ( $\mathrm{P}$ $<0.001$ ) higher in feces of subjects on the high red meat diet than those consuming a vegetarian diet.[14] However, mutations were not detected in the $K$-ras gene of exfoliated colonocytes. ${ }^{[42]}$

Heme iron - a pro-oxidant. The ingestion of heme iron from hemoglobin or myoglobin mediates the formation of lipid peroxidation and apparent total NOCs in the colon. ${ }^{[13,16,36,42]}$ The feeding of hemin (ferriheme), but not protoporphyrin

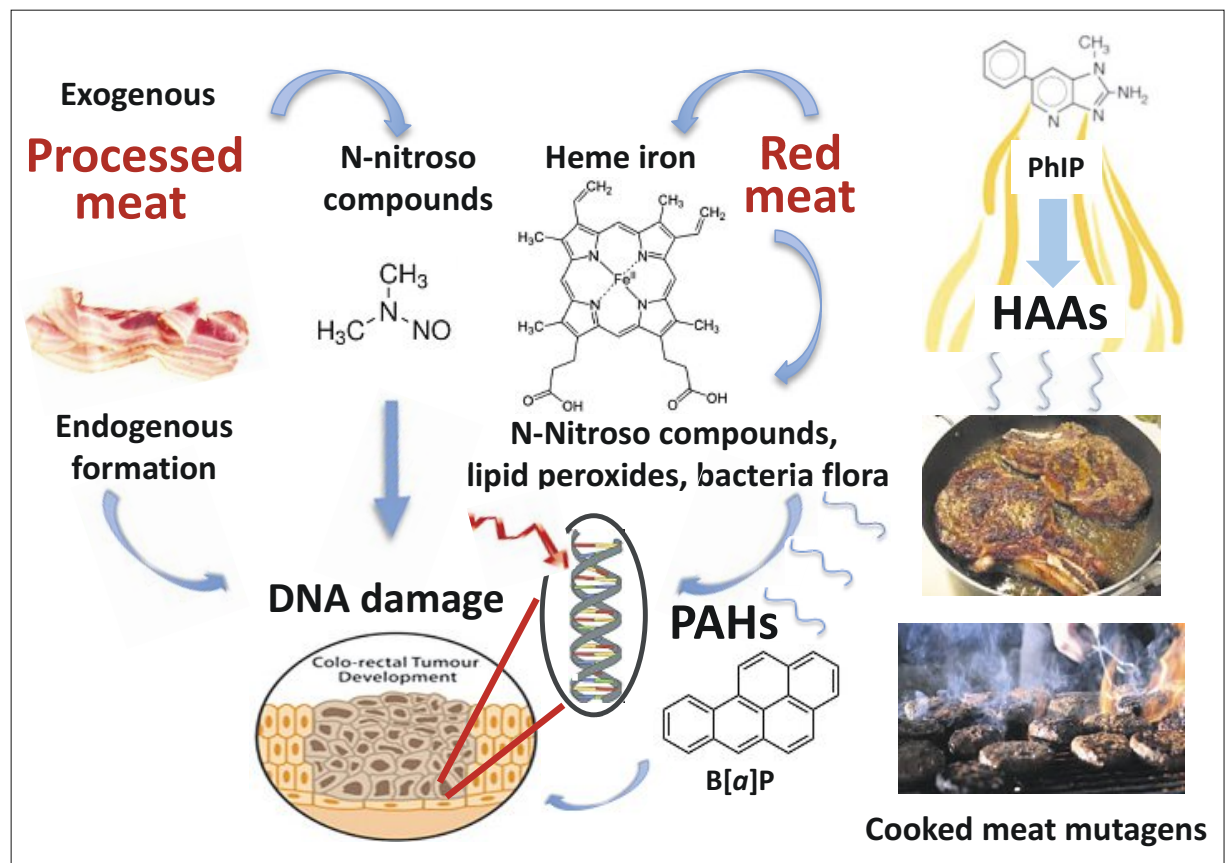

Fig. 1. Mechanisms of DNA damage in colorectum by genotoxicants and components in meat and modulating effects of the bacterial flora. Mechanisms are adapted from refs $[35,36]$ and citations within. 


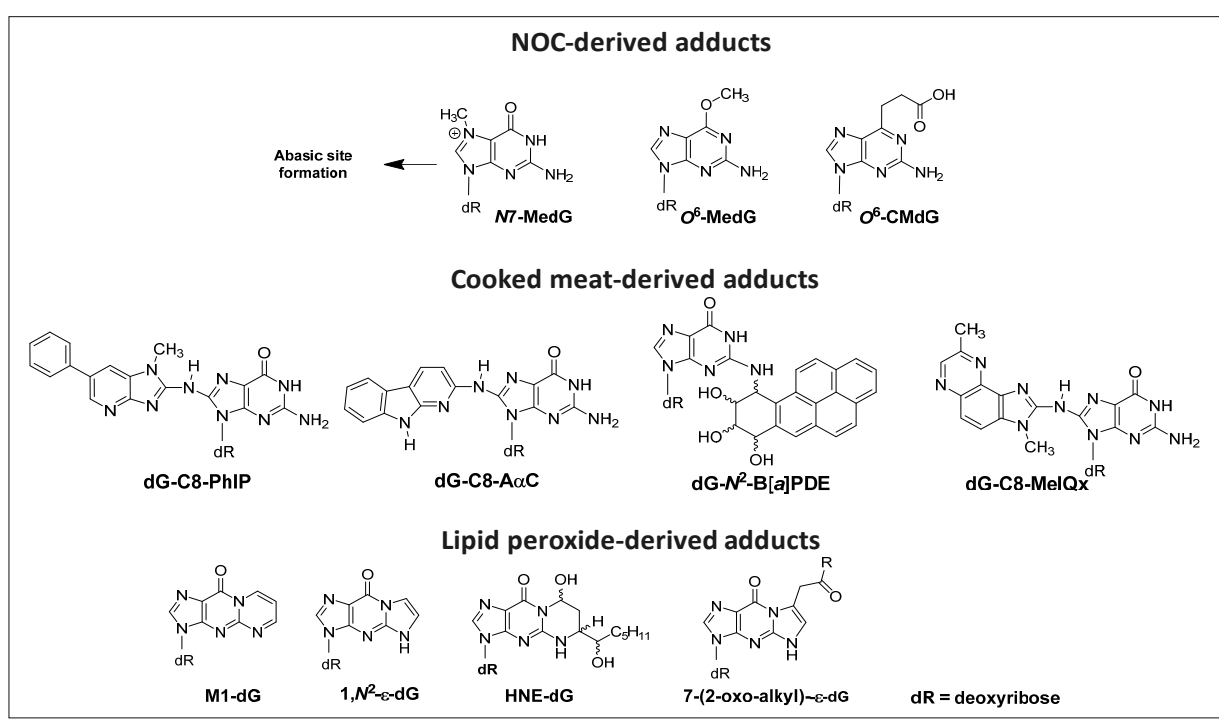

Fig. 2. Chemical structures of DNA adducts derived from prototypical NOCs, HAAs and PAHs, and lipid peroxides.

IX, ferric citrate or bilirubin leads to the formation of cytotoxic and potentially DNA-damaging agents, and cell proliferation of the colonic mucosa of rodents. ${ }^{[43]}$ Malondialdehyde (MDA) is one product of lipid peroxidation that reacts with $\mathrm{dG}$ to form the cyclic adduct 3-(2-deoxy- $\beta$-Derythropenta-furanosyl)pyrimido[1,2- $\alpha]$ purin-10(3H)-one 2'-deoxyguanosine (M1-dG). ${ }^{[44]}$ MDA and other genotoxic lipid oxidation products, such as those formed from 4-oxo-2-alkenals (Fig. 2), ${ }^{[45]}$ are hypothesized to be elevated in humans who eat processed or red meats. ${ }^{[16,46]}$

Heterocyclic aromatic amines and polycyclic aromatic hydrocarbons. HAAs, including 2-amino-1-methyl6-phenylimidazo[4,5- $b$ ]pyridine (PhIP), 2 -amino-3,8-dimethylimidazo $[4,5-f]$ quinoxaline (MeIQx) and 2-amino-9Hpyrido[2,3- $b$ ]indole $(\mathrm{A} \alpha \mathrm{C})$ are abundant HAAs formed in well-done cooked meats. HAAs undergo metabolism, by cytochrome P450 enzymes, to form genotoxic $N$-hydroxylated metabolites. [19] These metabolites undergo further metabolism with conjugation enzymes, such as $N$-acetyltransferases or sulfotransferases, to generate reactive intermediates that bind to DNA (Fig. 2). [32] PAHs, such as benzo $[a]$ pyrene $(\mathrm{B}[a] \mathrm{P})$, also undergo bioactivation by human cytochrome $\mathrm{P} 450$ enzymes to form genotoxic species. ${ }^{[47]}$ The reactive intermediates are anti-diolepoxides of the bay region of PAH molecules, although trans-dihydrodiols of some PAHs can contribute to DNA damage and oxidative stress through their oxidation to $o$-quinones. ${ }^{[48]} \mathrm{PAHs}$ that arise in tobacco smoke are also believed to contribute to lung cancer in smokers. ${ }^{[49]}$

$N$-glycolylneuraminic acid (Neu5Gc). Red meats are rich with glycans containing a non-human variant of sialic acid called $N$-glycolylneuraminic acid
(Neu5Gc). ${ }^{[50]}$ Neu5Gc is not biosynthesized in humans, but it is bioavailable and becomes incorporated in tissues of omnivores. ${ }^{[50]}$ Interactions of this antigen with circulating anti-Neu5Gc antibodies in a murine model have been shown to promote chronic inflammation, leading to reactive oxygen species that can contribute to carcinogenesis and tumor progression (Fig. 3). with permission from ref. [50].

\section{Methods to Detect DNA Adducts in Humans}

Despite the large body of epidemiology data on the risk of processed or red meat diet in the development of CRC, ${ }^{[11,13]}$ there is a paucity of physico-chemical data on the DNA adducts formed in the colorectum. The absence of specific biomarkers for distinguishing between DNA adducts occurring through dietary intake or from endogenous processes has hindered our ability to substantiate any of the proposed chemicals and biochemical mechanisms involved in CRC. ${ }^{32} \mathrm{P}$-postlabeling, immunohistochemistry (IHC), gas chromatography/mass spectrometry (GC/MS) and liquid chromatography mass spectrometry (LC/MS) have served as the major methods to measure DNA adducts in humans. The advantages and limitations of these technologies have been reviewed, [51-54] and the technologies are briefly highlighted here in context to the characterization of DNA adducts in colorectum.

\section{1 ${ }^{32}$ P-Postlabeling}

${ }^{32} \mathrm{P}$-Postlabeling remains the most commonly used method to screen for DNA adducts because it is a highly sensitive technique. ${ }^{[51]}$ The DNA is enzymatically digested to 3'-phospho-2'-deoxyribonucle-

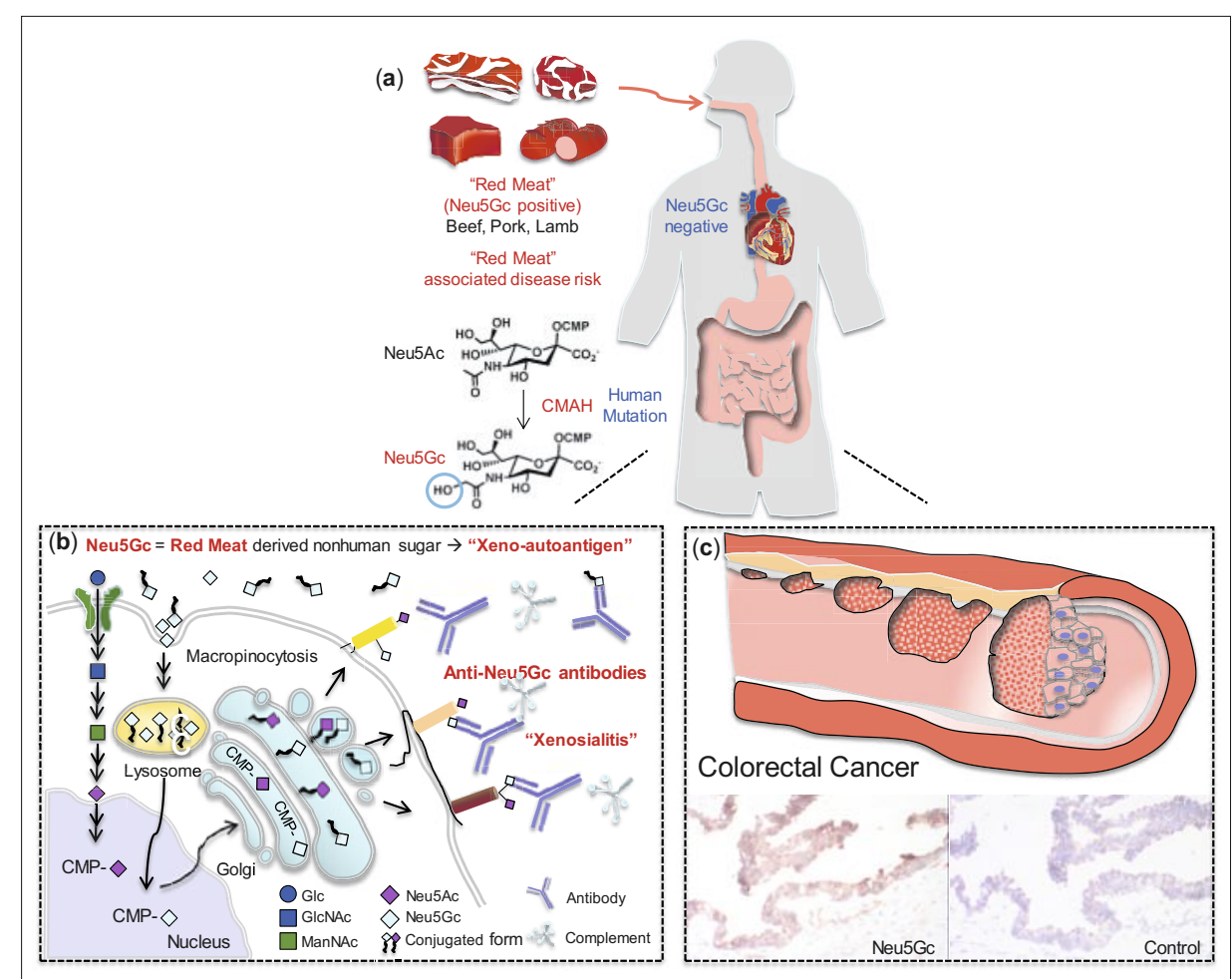

Fig. 3. Potential CRC risk associated with metabolic incorporation of non-human sialic acid $\mathrm{N}$-glycolylneuraminic acid (Neu5Gc) from red meat. (a) Neu5Gc is present in beef, pork, lamb, but humans cannot synthesize it. (b) Neu5Gc can be incorporated into human cells through the same pathway used for Neu5Ac recycling. (c) Endocytosed Neu5Gc is used as a substrate for the synthesis of sialylated glycans in the Golgi. Cell surface glycans containing Neu5Gc may be targeted by circulating anti-Neu5Gc antibodies and complement, leading to a human specific inflammation, termed xenosialitis. ${ }^{[50]}$ The figure was kindly provided by Dr. Kunio Kawanishi and adapted 
otides, and ${ }^{32} \mathrm{P}$-orthophosphate from $\left[\gamma^{32} \mathrm{P}\right]$ ATP is transferred to the $5^{\prime}-\mathrm{OH}$ position of the 2'-deoxyribonucleotide adduct, by polynucleotide kinase. The 5 '- ${ }^{32} \mathrm{P}$-labeled nucleotides are usually resolved by multidimensional thin-layer chromatography using autoradiography for detection or by HPLC with radiometric detection. The technique has revealed that human DNA is modified with many environmental and dietary chemicals, and endogenous electrophiles to form numerous putative DNA adducts some of which may occur in the colorectum. ${ }^{[55,56]}$ However, the identification and quantification of DNA adducts cannot be achieved by ${ }^{32} \mathrm{P}$-postlabeling. Thus, the conclusions drawn from epidemiological studies employing ${ }^{32} \mathrm{P}$-postlabeling have often provided ambiguous results about the role of diet, chemical exposures and their relationships to DNA adducts, and the impact of genetic polymorphisms in genes that encode for carcinogen metabolism enzymes on cancer risk. ${ }^{[57-59]}$

\subsection{Immunochemical Methods}

Several DNA adducts have been screened, by immunochemical methods, in human colorectal or other tissues. ${ }^{[38,60-63]}$ These methods employ ELISA (enzymelinked immunosorbent assay) plate-based assays, radio immunoassays, or slot-blot methods to screen for DNA adducts, using antibodies raised against carcinogentreated DNA or DNA adducts coupled to carrier proteins. Immunohistochemical (IHC) detection of DNA adducts in tissue section-cuts mounted on slides is another screening method and allows for the visualization of the DNA adduct within specific cell types of a tissue. ${ }^{52]}$ IHC is especially suitable for archived formalinfixed paraffin-embedded (FFPE) tissues for which there is a clinical diagnosis of disease. An important drawback of immuno-based detection methods is that the specificity of antibodies, even monoclonal antibodies, for DNA adducts is uncertain as they may cross-react with other DNA lesions or cellular components, leading to errors in identification and quantification. Also, immunodetection methods can only be performed on DNA lesions for which antibodies are available. Signals for putative colorectal adducts of $O^{6}-\mathrm{MedG},{ }^{[60,62]}$ $O^{6}-\mathrm{CMdG}^{[42]}$ and $\mathrm{M} 1-\mathrm{dG}^{[61]}$ have been detected by IHC or slot blot methods. A high red meat diet increased rectal $O^{6}$ MedG adduct levels in healthy subjects by $21 \%$ relative to baseline levels, based on immuno detection. ${ }^{[62]}$ In another study, the mean percentage of exfoliated colonocytes staining positive for $O^{6}-\mathrm{CMdG}$ in feces of subjects on a red meat diet was increased by 2.5 -fold compared to the levels for the same subjects on a vegetarian diet. ${ }^{[42]} \mathrm{M} 1-\mathrm{dG}$ was detected, by means of a slot blot method, in more than $90 \%$ of the colorectal specimens of men and women from European Prospective Investigation on Cancer. ${ }^{[61]}$

\subsection{Mass Spectrometry Methods}

GC/MS with electron impact ionization and more recently negative ion chemical ionization have been employed to measure DNA adducts (primarily used for oxidized DNA bases) where adduct structures can be corroborated from the MS fragmentation spectra. The DNA is usually hydrolyzed with acid or base to produce the aglycone adducts. ${ }^{[54]}$ DNA adducts require chemical derivatization to increase the volatility required for GC analysis. The derivatization process is often conducted at elevated temperature $\left(>100{ }^{\circ} \mathrm{C}\right)$. Thus, the DNA adducts must be stable to the harsh conditions of DNA hydrolysis and to elevated temperatures employed in GC/MS. The base hydrolysis of DNA was employed to recover PhIP from human colorectal DNA, followed by electron capture MS, which is also known as GC-negative ion chemical ionization (NICI)-MS.[64] Presumably, the liberated $\mathrm{PhIP}$ was derived from the $N-(2$ deoxyguanosine-8-yl)-PhIP (dG-C8PhIP). PhIP was detected at levels of several adducts per $10^{8}$ DNA bases in two out of six human colon samples, when assayed by this method. To the author's knowledge, there are no other reports on the analysis of DNA adducts in human colorectal tissue by GC/MS.

The online coupling of LC to electrospray ionization (ESI) MS is the most commonly used technology to measure many DNA adducts which would otherwise undergo thermal decomposition by GCMS.[65-67] Most DNA adducts are detected following nuclease digestion of the DNA to produce the modified 2'-deoxyribonucleoside adducts. ${ }^{[67]}$ Because of the basic properties of the nitrogenous nucleobase moieties, DNA adducts are usually analyzed in the positive ionization mode. A common feature of most DNA adducts is their propensity to lose the 2'-deoxyribose (dR) moiety (116 Da or 116.0473 Da in high-resolution accurate mass (HRAMS)), when subjected to collision-induced dissociation (CID). ${ }^{[68]}$ This transition is commonly used to measure DNA adducts by targeted $\mathrm{MS}^{2}$ methods employing triple quadrupole $\mathrm{MS}$, and more recently by ion trap (IT)/Orbitrap $\mathrm{MS}^{\mathrm{n}}$ scanning methods. ${ }^{[67,69-72]}$ However, there are no reports in the literature employing $\mathrm{LC} / \mathrm{MS}^{2}$ to measure 2'-deoxyribonucleoside DNA adducts in the colorectum from chemicals derived from processed red meat or cooked meats. Another approach is to analyze for the DNA adducts as the modified DNA base. Following formic acid hydrolysis of DNA, Orbitrap-HRAMS was employed using wide-selected ion monitoring or HRAMS/MS ${ }^{2}$ to screen for the aglycones of 30 putative DNA adducts in human colon; $O^{6}-\mathrm{CMdG}$ was tentatively identified as one lesion. ${ }^{[73]}$

\subsection{Other Methods to Detect DNA Damage}

There is one report on the detection of a putative $\mathrm{B}[a] \mathrm{P}$ DNA adduct in colorectum, following acid hydrolysis of DNA. The liberated tetraol $r-7, c-10, t-8, t-9$-tetrahydroxy-7,8,9,10-tetrahydro-B $[a] \mathrm{P}$ was detected, by HPLC/fluorescence, in four out of seven colon mucosa samples at levels ranging between 0.2 and 1.0 adducts per $10^{8}$ DNA bases. ${ }^{[74]}$ These findings were not confirmed by specific MS-based methods.

DNA damage has also been assessed by the Comet Assay. The alkaline comet assay detects DNA strand breaks (SBs) and alkali-labile sites at frequencies from a few hundred to several thousand breaks per eukaryote cell and can visualize DNA damage introduced by endogenous electrophiles or exposures to exogenous genotoxicants. ${ }^{[75]}$ The treatment of the genome with DNA glycosylases allows for measurement of damage other than SBs, where damaged bases in DNA are removed, resulting in the formation of apurinic/apyrimidinic (AP) sites, which are readily detected by the comet assay. The assay is sensitive and can screen for a broad range of types of DNA damage. However, the Comet Assay, like ${ }^{32} \mathrm{P}$-postlabeling and immunodetection methods, fails to identify the specific chemicals involved in DNA adduct formation. DNA damage in human colon of volunteers who consumed cooked meat was characterized by the Comet Assay. When volunteers ate a diet of hightemperature cooked red meat containing elevated levels of HAAs, rectal biopsy cell DNA damage increased, when measured by the Comet assay.[76] The DNA damage was reduced by nearly two-fold when the cooked meat was consumed with cruciferous vegetables, yogurt, and chlorophyllin tablets. ${ }^{[76]}$ These food components reduce the genotoxicity of HAAs in rodent studies, ${ }^{777,78]}$ suggesting a plausible role for HAAs in cooked meat in DNA damage of the rectum. ${ }^{[76]}$

\section{Factors that Modulate Carcinogenicity}

There are many dietary and host factors that can influence the biological potency of genotoxicants. Chemoprotective agents in the diet and beverages and the bacterial flora are important factors that impact the carcinogenic potential of genotoxicants in cooked meat. 


\subsection{Chemoprevention}

Numerous studies have reported protective beneficial health effects of naturally occurring phytochemicals, including polyphenolics and thiocyanates, found in cruciferous vegetables, foods, and beverages against carcinogens. ${ }^{[79,80]}$ Beneficial effects have also been reported on short chain fatty acid microbial metabolites, which are formed in fermented dairy products and regulate epithelial cell homeostasis. ${ }^{[81]}$ These biochemicals have been reported to exert protection towards dietary, tobacco-associated, and mycotoxin carcinogens. ${ }^{[80,82-85]}$ Wattenberg classified chemopreventive agents into three broad categories, with markedly different functions: 1) agents that can prevent the formation of carcinogenic compounds from their precursors or diminish carcinogen bioavailability; 2) agents that can block the metabolic activation of carcinogens, scavenge reactive intermediates, or alter metabolism by changes in the expression of enzymes of metabolism involved in bioactivation or detoxification; and 3) agents that can interfere in the process by which initiated cells progress to neoplasia. ${ }^{[82]}$ Recently certain chemicals have been shown to act on the repair and replication processes of damaged DNA, resulting in decreases in mutation frequency. ${ }^{[80]}$ It is also now recognized that dietary factors contribute to chemoprevention by modulating epigenetic events, including the DNA methylation status, that alters expression of genes involved in carcinogenesis. ${ }^{[86]}$

\subsection{The Role of Bacterial Flora in Colorectal Cancer}

Bacteria constitute about $90 \%$ of all cells in the human body, and it has been estimated that these bacteria are comprised of over 1000 different species. ${ }^{[9]}$ Trillions of commensal bacteria, termed 'the microbiota,' are in close proximity to a single layer of intestinal epithelial cells. Commensal bacteria are involved in the intestinal architecture and possess important homeostatic immune and metabolic functions. Commensal bacteria and their metabolites affect the proliferation and survival of epithelial cells and also provide protection against pathogens. ${ }^{[87]}$ The majority of microbes reside in the gastrointestinal tract in communities defined as the microbiome. The microbiome is dynamic and its composition and functionality are influenced by the diet, environment, and physiological changes, such as diseases. An unbalanced change in the microbiota ecosystem leads to dysbiosis and can result in the development of inflammatory bowel disease, metabolic syndrome, and initiate CRC. ${ }^{[87]} \mathrm{A}$ model of the microbial ecology involved in the onset of CRC and progression was proposed by Tjalsma, ${ }^{[9]}$ and termed the bacterial driver-passenger model. In this model, CRC development is initiated by over colonization of the colorectum with indigenous bacteria with pro-carcinogenic features - these microbes are termed bacterial drivers, and damage epithelial DNA and contribute to CRC initiation. Several candidate bacterial drivers have been identified and include superoxide-producing strains of Enterococcus faecalis, and colibactin-producing Escherichia coli strains. Colibactin is a potent genotoxin that can form DNA adducts and crosslinks; it induces DNA strand breaks and cell cycle arrest, and also promotes tumor growth. ${ }^{[88-91]}$ Other proinflammatory members of Bacteroides fragilis Enterobacteriaceae, such as Shigella, Citrobacter and Salmonella have been associated with early stages of CRC as possible bacterial drivers. ${ }^{[92]}$

There are also a number of bacteria that exert antimutagenic/anticarcinogenic effects. For example, certain strains of lactobacillus and bifidobacterium species inhibit DNA damage and decrease the incidence of colon carcinogenesis of 1,2-dimethylhydrazine and HAAs in rodents by either binding to the procarcinogens, catalyzing the detoxication of the chemicals, or by induction of the immune response. ${ }^{93-95]}$

Bacterial enzymes can metabolize procarcinogens. The enzymes include: $\beta$-glucuronidase, $\beta$-glycosidase, azoreductase, nitroreductase, and nitratereductase. ${ }^{[96]}$ For example, the glucuronide conjugates of HAAs and their $N$-hydroxylated HAAs, and those of hydroxylated PAHs can undergo enzymatic hydrolysis by $\beta$-glucuronidases of the bacterial flora, which liberate the aglycones that may exert genotoxic effects within the GI tract, or undergo enterohepatic circulation and modulate carcinogenic risk (Fig. 4). ${ }^{[97,98]}$
Eubacterium and Clostridium oxidize IQ-type compounds to form 7-oxo species, such as 2-amino-3-methyl-3Himidazo[4,5-f]quinolone (7-oxo-IQ) (Fig. 4). ${ }^{[99]}$ These compounds are directly mutagenic in the Ames test strain Salmonella; however, they are not carcinogenic in rodents. ${ }^{[100]}$ The human gut microbiota also can contribute to the detoxification of PhIP by forming 7-hydroxy-5-methyl-3-phenyl-6,7,8,9-7-tetrahydropyrido[ [3',2':4,5] imidazo[1,2-a]pyrimidin-5-ium chloride (PhIP-M1), a conjugate formed by Lactobacillus reuteri, Eubacterium hallii, and strains of Enterococcus in the presence of glycerol.[101-103] PhIP-M1 has been detected as a minor metabolite in human urine and feces. ${ }^{[104]}$ The human colon microbiota also catalyze the formation of 7-hydroxybenzo[a]pyrene in vitro. ${ }^{[105]} \mathrm{At}$ the elevated doses employed in carcinogenesis studies, the oral exposure to $\mathrm{B}[a] \mathrm{P}$ significantly altered the composition and the abundance of the gut microbiota and led to moderate inflammation in the ileal and colonic mucosa of C57BL/6 mice. ${ }^{[106]}$ Collectively, these findings highlight the complex effects of the diet, and the interplay of commensal and pathogenic bacteria microbiome on microbial composition and activity in the colon that impact human health and disease states.

\section{Conclusions}

Epidemiological studies have often linked the frequent consumption of processed meats and cooked red meats with an elevated risk for CRC. ${ }^{[11,13]}$ Multiple hypotheses have been proposed to explain the increased risk of CRC associated with meat consumption.[107] Many different classes of genotoxicants present in processed and

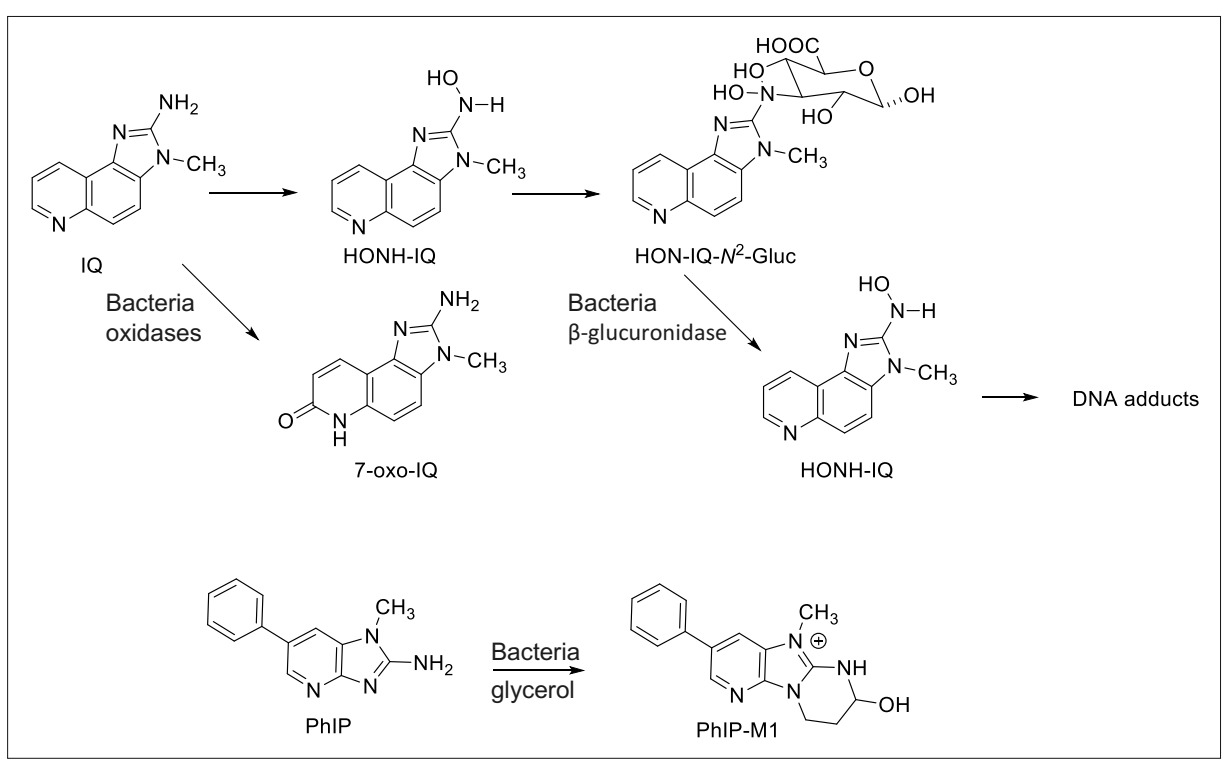

Fig. 4. Metabolism of HAAs by mammalian P450s (CYP) and UDP-glucuronosyltransferases (UGT), and metabolism of HAAs or their metabolites by bacterial gut flora. 
cooked meats are capable of forming promutagenic DNA adducts in humans, which can contribute to CRC. ${ }^{[13,31,46]}$ In addition, endogenous nitrosation processes produce reactive intermediates that can induce DNA damage, and possibly lead to mutations in the colonocytes. ${ }^{[14]}$ Pro-oxidants in cooked red and processed meats, including heme, ingested fats and lipid peroxidation products, ${ }^{[108]}$ and Neu5Gc ${ }^{[50]}$ may contribute to inflammation and tumor promotion, leading to the development of CRC. It is also important to consider the role of the bacterial flora of the gut in the development of CRC. Gut bacteria have critical homeostatic and immune functions, and are capable of metabolizing endogenous and xenobiotic chemicals, including the bioactivation and detoxification of carcinogens. ${ }^{[78,107]}$ The increased risk for CRC may not be associated with one single chemical, but due to the presence of a complex mixture of chemicals and bacterial flora acting on multiple stages of CRC development. ${ }^{[18]}$ Clearly, more human studies with controlled meat diets and the identification and quantification of colorectal biomarkers of DNA damage, such as DNA adducts, by specific mass spectrometric methods, and linking these adducts to mutations ${ }^{[109]}$ can advance our understanding of the chemicals in the diet and those produced endogenously that damage DNA and may contribute CRC risk. ${ }^{[32,110]}$

The IARC working group concluded that for every 50 grams of processed meat or 100 grams of red meat eaten, the relative risk of colon cancer was increased by about $18 \%$ compared to those individuals who ate the least meats. ${ }^{[10]}$ This relative risk is modest compared to the relative risk of developing lung cancer from smoking cigarettes, which ranges between 1000-3000\%.[111] Nevertheless, exposure to genotoxicants in the diet should be avoided. It should be recognized that consumption of red meat does have beneficial effects. Red meat is a nutritious food and an important source of protein with all essential amino acids, highly bioavailable iron, zinc, selenium, and $\mathrm{B}$ vitamins, especially vitamin B12 in the diet. ${ }^{[112]}$ There are ways to eat healthier meat products by avoiding the consumption of processed meats treated with nitrite or by not over-cooking or charring of red meat. The consumption of lean red meats in moderation, ${ }^{[2]}$ combined with poultry, fish, whole grains, vegetables, and fruits can provide a well-balanced and healthy diet.

\section{Acknowledgment}

The research conducted in the author's lab on cooked meat mutagens and colorectal cancer has been supported by National Institutes of Health Grants R01CA122320 and R01CA134700.
[1] 'Cancer Facts \& Figures 2018', American Cancer Society, Atlanta, Georgia, 2018.

[2] 'Food, Nutrition, Physical Activity, and the Prevention of Cancer: a Global Perspective', World Cancer Research Fund/American Institute for Cancer Research, 2007.

[3] D. G. Power, E. Gloglowski, S. M. Lipkin, Hematol. Oncol. Clin. North Am. 2010, 24, 837.

[4] L. Le Marchand, J. H. Hankin, L. R. Wilkens, L. M. Pierce, A. Franke, L. N. Kolonel, A. Seifried, L. J. Custer, W. Chang, A. Lum-Jones, T. Donlon, Cancer Epidemiol. Biomarkers Prev. 2001, 10, 1259.

[5] L. Le Marchand, T. Donlon, A. Seifried, L. R. Wilkens, Cancer Epidemiol. Biomarkers Prev. 2002, 11, 1019.

[6] S. Kury, B. Buecher, S. Robiou-du-Pont, C. Scoul, V. Sebille, H. Colmann, C. Le Houérou, T. Le Neel, J. Bourdon, R. Faroux, J. Ollivry, B. Lafraise, L. D. Chupin, S. Bézieau, Cancer Epidemiol. Biomarkers Prev. 2007, 16, 1460.

[7] E. R. Fearon, B. Vogelstein, Cell 1990, 61, 759.

[8] D. Colussi, G. Brandi, F. Bazzoli, L. Ricciardiello, Int. J. Mol. Sci. 2013, 14, 16365.

[9] H. Tjalsma, A. Boleij, J. R. Marchesi, B. E. Dutilh, Nat. Rev. Microbiol. 2012, 10, 575.

[10] V. Bouvard, D. Loomis, K. Z. Guyton, Y. Grosse, F. E. Ghissassi, L. Benbrahim-Tallaa, N. Guha, H. Mattock, K. Straif, International Agency for Research on Cancer Monograph Working Group, Lancet Oncol. 2015, 16, 1599.

[11] T. Norat, S. Bingham, P. Ferrari, N. Slimani, M. Jenab, et al., J. Natl. Cancer Inst. 2005, 97, 906.

[12] D. Kim, Y. J. Lee, H. Y. Ryu, J. H. Lee, H. K. Kim, E. Kim, J. D. Moon, D. D. Chang, H. S. Yoon, J. Appl. Toxicol. 2013, 33, 63.

[13] D. E. Corpet, S. De Smet, D. Demeyer, Meat Sci. 2014, 98, 115.

[14] A. M. Joosen, G. G. Kuhnle, S. M. Aspinall, T. M. Barrow, E. Lecommandeur, A. Azqueta, A. R. Collins, S. A. Bingham, Carcinogenesis 2009, 30, 1402.

[15] R. L. Santarelli, J. L. Vendeuvre, N. Naud, S Tache, F. Gueraud, M. Viau, C. Genot, D. E. Corpet, F. H. Pierre, Cancer Prev. Res. (Phila) 2010, 3, 852 .

[16] N. M. Bastide, F. Chenni, M. Audebert, R. L. Santarelli, S. Tache, N. Naud, M. Baradat, I. Jouanin, R. Surya, D. A. Hobbs, G. G. Kuhnle, I. Raymond-Letron, F. Gueraud, D. E. Corpet, F. H. Pierre, Cancer Res. 2015, 75, 870 .

[17] W. Lijinsky, Mutat. Res. 1999, 443, 129.

[18] D. Demeyer, B. Mertens, S. De Smet, M. Ulens, Crit. Rev. Food Sci. Nutr. 2016, 56, 2747.

[19] T. Sugimura, K. Wakabayashi, H. Nakagama, M. Nagao, Cancer Sci. 2004, 95, 290

[20] J. S. Felton, M. Jagerstad, M. G. Knize, K. Skog, K. Wakabayashi, in 'Food Borne Carcinogens Heterocyclic Amines', Eds. M. Nagao, T. Sugimura, John Wiley \& Sons Ltd., Chichester, England, 2000, p. 31.

[21] D. H. Phillips, Mutat. Res. 1999, 443, 139.

[22] A. Sancar, J. T. Reardon, Adv. Protein Chem. 2004, 69, 43 .

[23] J. C. Delaney, J. M. Essigmann, Chem. Res. Toxicol. 2008, 21, 232.

[24] R. Doll, R. Peto, J. Natl. Cancer Inst. 1981, 66, 1191.

[25] A. J. Cross, R. Sinha, Environ. Mol. Mutagen. 2004, 44,44

[26] S. Rohrmann, S. Hermann, J. Linseisen, Am. J. Clin. Nutr. 2009, 89, 1418.

[27] A. Sander, J. Linseisen, S. Rohrmann, Cancer Causes Control 2011, 22, 109

[28] U. Nothlings, J. F. Yamamoto, L. R. Wilkens, S. P. Murphy, S. Y. Park, B. E. Henderson, L. N. Kolonel, L. Le Marchand, Cancer Epidemiol. Biomarkers Prev. 2009, 18, 2098.
[29] S. Nowell, B. Coles, R. Sinha, S. MacLeod, R. D. Luke, C. Stotts, F. F. Kadlubar, C. B. Ambrosone, N. P. Lang, Mutat. Res. 2002 506-507, 175

[30] S. Nowell, D. L. Ratnasinghe, C. B Ambrosone, S. Williams, T. Teague-Ross, L. Trimble, G. Runnels, A. Carrol, B. Green, A. Stone, D. Johnson, G. Green, F. F. Kadlubar, N P. Lang, Cancer Epidemiol. Biomarkers Prev. 2004, 13, 270.

[31] W. Zheng, S. A. Lee, Nutr. Cancer 2009, 61 , 437.

[32] R. J. Turesky, L. Le Marchand, Chem. Res. Toxicol. 2011, 24, 1169.

[33] M. W. Himmelstein, P. J. Boogaard, J. Cadet, P. B. Farmer, J. H. Kim, E. A. Martin, R. Persaud, D. E. Shuker Crit. Rev.Toxicol. 2009, 39, 679.

[34] A. M. Jarabek, L. H. Pottenger, L. S. Andrews, D. Casciano, M. R. Embry, J. H. Kim, R. J. Preston, R. J. Reddy, R. Shoeny, D. Shuker, J. Skare, J. Swenberg, G. M. Williams, E. Zeiger, Crit. Rev. Toxicol. 2009, 39, 659 .

[35] S. Kim, J. Guo, M. G. O'Sullivan, D. D. Gallaher, R. J. Turesky, Environ. Mol. Mutagen. 2016, 57, 125 .

[36] N. M. Bastide, F. H. Pierre, D. E. Corpet, Cancer Prev. Res. (Phila) 2011, 4, 177.

[37] C. S. Yang, J.-S. H. Yoo, H. Ishizaki, J. Hong, Drug Metabol. Rev. 1990, 22, 147.

[38] K. L. Harrison, M. Wood, N. P. Lees, C. N Hall, G. P. Margison, A. C. Povey, Chem. Res Toxicol. 2001, 14, 295.

[39] K. L. Harrison, R. Jukes, D. P. Cooper, D. E. Shuker, Chem. Res. Toxicol. 1999, 12, 106.

[40] E. Gottschalg, G. B. Scott, P. A. Burns, D. E Shuker, Carcinogenesis 2007, 28, 356.

[41] N. P. Lees, K. L. Harrison, C. N. Hall, G. P. Margison, A. C. Povey, Carcinogenesis 2004 25, 1243.

[42] M. H. Lewin, N. Bailey, T. Bandaletova, R. Bowman, A. J. Cross, J. Pollock, D. E. Shuker, S. A. Bingham, Cancer Res. 2006, 66, 1859.

[43] A. L. Sesink, D. S. Termont, J. H. Kleibeuker, R. Van der Meer, Cancer Res. 1999, 59, 5704.

[44] L. J. Marnett, J. P. Plastaras, Trends Genet. 2001, 17, 214

[45] Y. Kawai, E. Nuka, J. Clin. Biochem. Nutr 2017, 1 .

[46] M. Oostindjer, J. Alexander, G. V. Amdam, G. Andersen, N. S. Bryan, D. Chen, D. E. Corpet, S. De Smet, L. O. Gragsted, A. Haug, A. H Karlsson, G. Kleter, T. M. de Kok, B. Kulseng, A. L. Milkowski, R. J. Martin, A. M. Pajari, J. E. Paulson, J. Pickova, K. Rudi, M. Sodring, D. L. Weed, B. Egelandsdal, Meat Sci. 2014, 97, 583.

[47] T. Shimada, C. L. Hayes, H. Yamazaki, S Amin, S. S. Hecht, F. P. Guengerich, T. R. Sutter, Cancer Res. 1996, 56, 2979.

[48] T. M. Penning, Chem. Res. Toxicol. 2014, 27 , 1901

[49] 'IARC Monographs on the Evaluation of Carcinogenic Risks to Humans. Tobacco smoke and involuntary smoking', Vol. 83, International Agency for Research on Cancer, Lyon, France, 2002.

[50] F. Alisson-Silva, K. Kawanishi, A. Varki, Mol. Aspects Med. 2016, 51, 16.

[51] D. H. Phillips, Cancer Lett. 2012, 334, 5

[52] M. C. Poirier, R. M. Santella, A. Weston, Carcinogenesis 2000, 21, 353 .

[53] J. J. Klaene, V. K. Sharma, J. Glick, P. Vouros, Cancer Lett. 2013, 334, 10.

[54] M. Dizdaroglu, Mutat. Res. Rev. Mutat. Res. 2015, 763, 212.

[55] A. Pfohl-Leszkowicz, Y. Grosse, V. Carriere, P. H. Cugnenc, A. Berger, F. Carnot, P. Beaune, I de Waziers, Cancer Res. 1995, 55, 5611.

[56] A. Umemoto, A. Kajikawa, M. Tanaka, K. Hamada, M. J. Seraj, A. Kubota, M. Nakayama, T. Kinouchi, Y. Ohnishi, K. K. Yamashita, Carcinogenesis 1994, 15, 901. 
[57] A. Agudo, M. Peluso, A. Munnia, L. LujanBarroso, M. J. Sanchez, E. Molina-Montes, E. Sanchez-Cantalejo, C. Navarro, M.-J. Tormo, M.-D. Chirlaque, A. Barricarte, E. Ardanaz, P. Amiano, M. Dorronsoro, J. Ramon Quiros, S. Piro, C. Bonet, N. Sala, C. A. Gonzalez, Cancer Epidemiol. Biomarkers Prev. 2012, 21, 685.

[58] F. Ricceri, R. W. Godschalk, M. Peluso, D. H. Phillips, A. Agudo, P. Georgiadis, S. Loft, A. Tjonneland, O. Raaschou-Nielsen, D. Palli, F. Perera, R. Vermeulen, E. Tailoi, R. J. Sram, A. Munnia, F. Rosa, A. Allione, G. Matullo, P. Vineis, Cancer Epidemiol. Biomarkers Prev. 2010, 19, 3174.

[59] V. Ho, S. Peacock, T. E. Massey, R. W. Godschalk, F. J. van Schooten, J. E. Ashbury, S. J. Vanner, W. D. King, Environ. Mol. Mutagen. 2015, 56, 609.

[60] A. C. Povey, C. N. Hall, A. F. Badawi, D. P. Cooper, P. J. O'Connor, Gut 2000, 47, 362

[61] C. Leuratti, M. A. Watson, E. J. Deag, A Welch, R. Singh, E. Gottschalg, L. J. Marnett, W. Atkin, N. E. Day, D. E. Shuker, S. A. Bingham, Cancer Epidemiol. Biomarkers Prev. 2002, 11, 267

[62] R. K. Le Leu, J. M. Winter, C. T. Christophersen, G. P. Young, K. J. Humphreys, Y. Hu, S. W. Gratz, R. B. Miller, D. L. Topping, A. R. Bird, M. A. Conlon, Br. J. Nutr. 2015, 114, 220.

[63] M. M. Pratt, K. John, A. B. MacLean, S. Afework, D. H. Phillips, M. C. Poirier, Int. J. Environ. Res. Public Health 2011, 8, 2675.

[64] M. D. Friesen, K. Kaderlik, D. Lin, L. Garren, H. Bartsch, N. P. Lang, F. F. Kadlubar, Chem. Res. Toxicol. 1994, 7, 733.

[65] N. Tretyakova, M. Goggin, D. Sangaraju, G. Janis, Chem. Res. Toxicol. 2012, 25, 2007.

[66] S. Liu, Y. Wang, Chem. Soc. Rev. 2015, 44, 7829.

[67] J. Guo, R. J. Turesky, Curr. Protoc. Nucleic Acid Chem. 2016, 66, 7241.

[68] S. M. Wolf, P. Vouros, Chem. Res. Toxicol. 1994, 7, 82 .

[69] E. E. Bessette, A. K. Goodenough, S. Langouet, I. Yasa, I. D. Kozekov, S. D. Spivack, R. J. Turesky, Anal. Chem. 2009, 81, 809.

[70] D. Gu, R. J. Turesky, Y. Tao, S. A. Langouet, G. C. Nauwelaers, J.-M. Yuan, D. Yee, M. C. Yu, Carcinogenesis 2012, 33, 124

[71] S. Xiao, J. Guo, B. H. Yun, P. W. Villalta, S. Krishna, R. Tejpauö, P. Murugan, C. J. Weight, R. J. Turesky, Anal. Chem. 2016, 88, 12508.

[72] B. H. Yun, T. A. Rosenquist, V. Sidorenko, C. R. Iden, C. H. Chen, Y.-S. Pu, R. Bonala, F. Johnson, K. G. Dickman, A. P. Grollman, R. J. Turesky, Chem. Res. Toxicol. 2012, 25, 1119.

[73] L. Y. Hemeryck, A. I. Decloedt, J. Vanden Bussche, K. P. Geboes, L. Vanhaecke, Anal. Chim Acta 2015, 892, 123.

[74] K. Alexandrov, M. Rojas, F. F. Kadlubar, N P. Lang, H. Bartsch, Carcinogenesis 1996, 17, 2081 .
[75] S. A. S. Langie, A. Azqueta, A. R. Collins, Front. Genet. 2015, 6, 266.

[76] D. T. Shaughnessy, L. M. Gangarosa, B. Schliebe, D. M. Umbach, Z. Xu, B. Macintosh, M. G. Knize, P. P. Matthews, A. E. Swank, R. S. Sandler, D. M. DeMarini, J. A. Taylor, PLoS One 2011, 6, e18707.

[77] J. V. Higdon, B. Delage, D. E. Williams, R. H. Dashwood, Pharmacol. Res. 2007, 55, 224.

[78] G. E. Walton, G. R. Gibson, in 'Nutrition and Health: Bioactive Compounds and Cancer', Eds. J. A. Milner, D. F. Romagnolo, Humana Press, New York, 2010, p. 181.

[79] P. Talalay, J. W. Fahey, J. Nutr. 2001, 131, 3027S.

[80] R. H. Dashwood, Mutat. Res. 2002, 511, 89

[81] P. M. Smith, M. R. Howitt, N. Panikov, M. Michaud, C. A. Gallini, Y.-M. Bohlooly, J. N. Glickman, W. S. Garrett, Science 2013, 341, 569.

[82] L. W. Wattenberg, Cancer Res. 1985, 45, 1.

[83] L. W. Wattenberg, Cancer Res. 1992, 52, 2085s.

[84] S. S. Hecht, F. Kassie, D. K. Hatsukami, Nat. Rev. Cancer 2009, 9, 476.

[85] T. W. Kensler, P. A. Egner, J. B. Wang, Y. R Zhu, B. C. Zhang, P. X. Lu, J. G. Chen, G. S Qian, S. Y. Kuang, P. E. Jackson, S. J. Gange, L. P. Jacobson, A. Munoz, J. D. Groopman, Gastroenterology 2004, 127, S310.

[86] E. Ho, L. M. Beaver, D. E. Williams, R. H Dashwood, Adv. Nutr. 2011, 2, 497.

[87] R. Martin, S. Miquel, J. Ulmer, N. Kechaou, P. Langella, L. G. Bermudez-Humaran, Microb. Cell Fact 2013, 12, 71.

[88] J. P. Nougayrede, S. Homburg, F. Taieb, M. Boury, E. Brzuszkiewicz, G. Gottschalk, C. Buchriesser, J. Hacker, U. Dobrindt, E. Oswald, Science 2006, 313, 848.

[89] G. Cuevas-Ramos, C. R. Petit, I. Marcq, M. Boury, E. Oswald, J. P. Nougayrède, Proc Natl. Acad. Sci. USA 2010, 107, 11537.

[90] G. Dalmasso, A. Cougnoux, J. Delmas, A Darfeuille-Michaud, R. Bonnet, Gut Microbes 2014, 5, 675 .

[91] M. I. Vizcaino, J. M. Crawford, Nat. Chem 2015, 7, 411 .

[92] M. Candela, S. Turroni, E. Biagi, F. Carbonero, S. Rampelli, C. Fiorentini, P. Brigidi, World J. Gastroenterol. 2014, 20, 908.

[93] B. R. Goldin, S. L. Gorbach, J. Natl. Cancer Inst. 1980, 64, 263.

[94] B. S. Reddy, A. Rivenson, Cancer Res. 1993, $53,3914$.

[95] M. Zsivkovits, K. Fekadu, G. Sontag, U. Nabinger, W. W. Huber, M. Kundi, A Chakraborty, H. Foissy, S. Knasmüller, Carcinogenesis 2003, 24, 1913.

[96] I. R. Rowland, Curr. Pharm. Des. 2009, 15, 1524.

[97] C. Humblot, M. Murkovic, L. Rigottier-Gois, M. Bensaada, A. Bouclet, C. Andrieux, J. Anba, S. Rabot, Carcinogenesis 2007, 28, 2419.
[98] J. Alexander, H. Wallin, O. J. Rossland, K. E. Solberg, J. A. Holme, G. Becher, R. Andersson, S. Grivas, Carcinogenesis 1991, 12, 2239.

[99] R. L. Van Tassell, D. G. Kingston, T. D. Wilkins, Mutat. Res. 1990, 238, 209.

[100] J. H. Weisburger, A. Rivenson, D. G. Kingston, T. D. Wilkins, R. L. Van Tassell, M. Nagao, T. Sugimura, Y. Hara, Princess Takamatsu Symp. 1995, 23, 240.

[101] L. Vanhaecke, N. Van Hoof, W. Van Brabandt, B. Soenen, A. Heyerick, N. De Kimpe, D. De Keukeleire, W. Verstraete, T. Van de Wiele, $J$. Agric. Food Chem. 2006, 54, 3454.

[102] M. I. Fekry, C. Engels, J. Zhang, C. Schwab, C. Lacroix, S. J. Sturla, C. Chassard, Environ. Microbiol. Rep. 2016, 8, 201.

[103] C. Engels, C. Schwab, J. Zhang, M. J. Stevens, C. Bieri, M.-O. Ebert, K. McNeill, S. J. Sturla, C. Lacroix, Sci. Rep. 2016, 6, 36246.

[104] L. Vanhaecke, M. G. Knize, H. Noppe, H. De Brabander, W. Verstraete, T. Van de Wiele, Food Chem. Toxicol. 2008, 46, 140.

[105] T. Van de Wiele, L. Vanhaecke, C. Boeckaert, K. Peru, J. Headley, W. Verstraete, S. Siciliano, Environ. Health Persp. 2005, 113, 6.

[106] C. Ribiere, P. Peyret, N. Parisot, C. Darcha, P. J. Dechelotte, N. Barnich, E. Peyretaillade, D. Boucher, Sci. Rep. 2016, 6, 31027.

[107] E. M. Quigley, Gastroenterol. Hepatol. (N Y) 2013, 9, 560.

[108] P. Boyle, J. S. Langman, BMJ 2000, 321, 805.

[109] L. B. Alexandrov, S. Nik-Zainal, D. C. Wedge, S. A. Aparicio, S. Behjati, A. V. Biankin, G. R. Bignell, N. Bolli, A. Borg, A. L. Børresen-Dale, S. Boyault, B. Burkhardt, A. P. Butler, C. Caldas, H. R. Davies, C. Desmedt, R. Eils, J. E. Eyfjörd, J. A Foekens, M. Greaves, F. Hosoda, B. Hutter, T. Ilicic, S. Imbeaud, M. Imielinski, N. Jäger, D. T. Jones, D. Jones, S. Knappskog, M. Kool, S. R. Lakhani, C. López-Otín, S. Martin, N. C. Munshi, H. Nakamura, P. A. Northcott, M. Pajic, E. Papaemmanuil, A. Paradiso, J. V. Pearson, X. S. Puente, K. Raine, M. Ramakrishna, A. L. Richardson, J. Richter, P. Rosenstiel, M. Schlesner, T. N. Schumacher, P. N. Span, J. W. Teague, Y. Totoki, A. N. Tutt, R. Valdés-Mas, M. M. van Buuren, L. van 't Veer, A. Vincent-Salomon, N. Waddell, L. R. Yates, Australian Pancreatic Cancer Genome Initiative, ICGC Breast Cancer Consortium, ICGC MMML-Seq Consortium, ICGC PedBrain, J. Zucman-Rossi, P. A. Futreal, U. McDermott, P. Lichter, M. Meyerson, S. M. Grimmond, R. Siebert, E. Campo, T. Shibata, S. M. Pfister, P. J. Campbell, M. R. Stratton, Nature 2013, 500, 415.

[110] E.-S. Hwang, P. E. Bowen, Crit. Rev. Food Sci. Nutr. 2007, 47, 27.

[111] D. M. Klurfeld, Animal Front. 2018, in Press.

[112] D. M. Klurfeld, Meat Sci. 2015, 109, 86. 